\title{
IAMJ
}

INTERNATIONAL

AYURVEDIC

MEDICAL JOURNAL

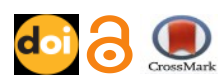

Research Article

ISSN: 2320-5091

Impact Factor: 6.719

\section{MANAGEMENT OF ESSENTIAL HYPERTENSION USING HERBAL FORMULATION WITH AND WITHOUT GOKSHURA KWATHA - A COMPARATIVE STUDY}

\author{
$\underline{\text { Pooja Gautam }}^{1}$, Ramesh Kumar Chaturvedi ${ }^{2}$, Shraddha Sharma ${ }^{3}$ \\ ${ }^{1}$ Post Graduate scholar, Final year, Department of Kaya Chikitsa \\ Pt. Khushilal Sharma Govt. (Auto.) College and Institute, Bhopal, Madhya Pradesh, India \\ ${ }^{2}$ Ayurved Medical Officer, Pratappur, Distt.- Satna, Madhya Pradesh, India \\ ${ }^{3}$ Lecturer, Department of Kaya Chikitsa \\ Pt. Khushilal Sharma Govt. (Auto.) College and Institute, Bhopal, Madhya Pradesh, India
}

Corresponding Author: pooja03gautam@gmail.com

https://doi.org/10.46607/iamj0209042021

(Published online: April 2021)

Open Access

(C) International Ayurvedic Medical Journal, India 2021

Article Received: 16/03/2021 - Peer Reviewed: 19/03/2021 - Accepted for Publication: 20/03/2021

Check for updates

\begin{abstract}
Hypertension is one of the major causes of cardiovascular morbidity and mortality worldwide. It is a global health problem affecting the people of different ethnicity and ages around the world. An estimated 1.13 billion people worldwide have hypertension, most (two-thirds) living in low- and middle-income countries. According to WHO (2015) the overall prevalence of hypertension in India was $24.2 \%$ and $22 \%$ among the men and women respectively. Hypertension is called a silent killer, non-communicable chronic disease because it rarely exhibits symptoms before it damages vital organs like kidney, brain or heart. In Ayurveda there is not a single disease which resemble with hypertension, but physician should understand the disease through Dosha, Dushya, Samprapti and initiate the treatment. A lot of potent modern antihypertensive drugs are available but none of them are free from untoward side-effects. So, a clinical study was done using herbal formulation containing Sarpaghandha, Sankhpushpi, Arjuna, Jatamansi and Ashwagandha in the form of Ghanvati. A comparative study was done as this Ghanvati was given with and without Gokshur kwath. For clinical study 52 (Group A- 25 and Group B- 27) clinically diagnosed patients of essential hypertension who fulfil inclusion criteria were selected irrespective of their age, sex, religion, occupation etc. and simple random sampling technique was followed for grouping the patients into 2 groups. All
\end{abstract}


the patients selected for the clinical trial were divided in two groups 'A' and 'B'. Patients of Group A were given $250 \mathrm{mg}$ of Ghanvati two times a day with water as Anupan and patients of Group B were given $250 \mathrm{mg}$ of Ghanvati with water as Anupan and Gokshur kwath both two times a day. Duration of the study for each group was 30 days. The present study showed that herbal formulation is also effective in the management of essential hypertension.

Keywords: Essential hypertension, Ghanvati

\section{INTRODUCTION}

Hypertension (HTN or HT), also known as high blood pressure or arterial hypertension, is a chronic medical condition in which the blood pressure in the arteries is persistently elevated. Hypertension is one of the major causes of cardiovascular morbidity and mortality worldwide. It is a global health problem affecting the people of different ethnicity and ages around the world. It is an asymptomatic medical condition in which systemic arterial blood pressure is elevated beyond the normal value. According to 2010 guidelines of 'European Society of Cardiology' and the 'European Society of Hypertension' hypertension is defined as office SBP values $\geq 140 \mathrm{~mm}$ of $\mathrm{Hg}$ and DBP values $\geq 90$ $\mathrm{mm}$ of $\mathrm{Hg}^{1}$.

- According to WHO (2015) the overall prevalence of hypertension in India was $24.2 \%$ and $22 \%$ among the men and women respectively ${ }^{2}$. Hypertension is called a silent killer, noncommunicable chronic disease because it rarely exhibits symptoms before it damages vital organs like kidney, brain or heart. It is estimated that by 2025, the global targets for non-communicable diseases is to reduce the prevalence of hypertension by $25 \%{ }^{3}$ and this need multidisciplinary efforts.

Following factors made me to go for clinical study on Essential hypertension:

- Essential hypertension is one of the common complaints of this modern era and is silent killer of mankind.

- It is a risk factor for all clinical manifestations of atherosclerosis.

- It is an independent predisposing factor for heart failure, coronary artery disease, stroke, renal disease and peripheral arterial disease and rarely exhibits symptoms before it damages vital organs like kidney, brain or heart.
- In Ayurveda there is not a single disease which resembles with hypertension but physician should understand the disease through Dosha, Dushya, Samprapti and initiate the treatment Hypertension is one of such diseases that is not described in Ayurveda as such, the reasons implicated are that it has no clear classical symptoms but is rather a machine diagnostic disease. In Ayurveda although there is no clinical entity available in classics however there are certain pathological conditions which can be considered to manifest some of the features comparable to that of Hypertension like Pittavritavata, Pittavrita Udana, Pittavritavyana, Pranavritaudana,

In majority of patients with high blood pressure, the cause is unknown and is classified as primary or essential hypertension. A small portion of patients have a specific cause of their high blood pressure, which is classified as secondary hypertension.

\section{Aim \& Objectives:}

- To evaluate the efficacy of Herbal formulation in the management of hypertension.

- To evaluate the efficacy of Herbal formulation along with Gokshura kwatha in the management of hypertension.

To compare the efficacy of Herbal formulation \& Herbal formulation along with Gokshura kwatha in the management of Hypertension.

\section{Material \& Methods:}

\section{a. Source of the patients}

For the present study patients of Essential hypertension fulfilling the criteria of diagnosis and criteria of inclusion were randomly selected from OPD (of Kayachikitsa department) and IPD of Pt. Khushilal Sharma Govt. (Auto) Ayurveda Hospital, Bhopal. 


\section{- Sampling and grouping}

Total 52 patients were registered and divided randomly into two groups viz. Group A and Group B.

Group A: 25 patients of this group were treated with Herbal formulation.

- Group B: 27 patients of this group were treated with Herbal formulation along with Gokshura kwatha.

\section{- Drug review}

$>$ Group A: Herbal formulation

The Herbal formulation contains the following drugs namely Sankhpusphi (Convolvuluspluricaulis), Arjun (Terminalia arjuna), and Ashwagandha (Withaniasomnifera) taken in equal quantity and the rest two drugs Sarpaghandha (Rauwolfia serpentina) and Jatamansi (Nordostachysjatamansi) each in half of the quantity of any one mentioned above then Ghanvati is prepared as mentioned in ayurvedic classics .

Dose: 2-tab (each $250 \mathrm{mg}$ ) BID, in the form of ghanvati after meal for 30 days

Follow up: will be on $7^{\text {th }}, 15^{\text {th }}$ and $30^{\text {th }}$ day

Anupan: Lukewarm water

$>$ Group B: Herbal formulation with Gokshura kwatha

Dose: 2-tab (each 250mg) BID in the form of Ghanvati after meal and kwatha $(20 \mathrm{ml}) \mathrm{BD}$ for 30 days
Anupan: Lukewarm water

Duration: 30 days

b. Selection Criteria

> Inclusion Criteria:

- Patients of either sex between the age of 40 years to 65 years.

- Patient having elevated blood pressure with or without clinical symptoms as described in ayurvedic and modern medicine.

- Patients having elevated blood pressure either systolic or diastolic or both are included as mentioned below.

$\mathrm{SBP}<159 \mathrm{mmHg} \& \geq 140 \mathrm{mmHg}$

DBP $<99 \mathrm{mmHg} \& \geq 90 \mathrm{mmHg}$

- Allopathy medicine of patient was stopped during the study period.

$>$ Exclusion Criteria:

- Patients having Renal or Hepatic disease.

- Complicated hypertensive case e.g. cardiovascular disease.

- Pregnant.

- Diabetic patients with uncontrolled sugar condition.

- Patients having chronic systemic illness

- Patients not willing for written consent

c. Criteria for diagnosis:

\section{Objective Criteria:}

The main diagnostic tool adopted will be measuring elevated BP in suitable position.

Table 1: JNC \& WHO criteria for Diagnosis Hypertension.

\begin{tabular}{|l|l|c|}
\hline Category of HTN & Systolic BP $(\mathrm{mmHg})$ & Diastolic BP $(\mathrm{mmHg})$ \\
\hline Stage 1 Hypertension & $140-159$ & $90-99$ \\
\hline
\end{tabular}

d. Lab investigations:

- Random Blood sugar,

- Lipid profile

- ECG
- The relative extent of all these criteria was recorded according to the rating scale in each patient at the initial stage and subsequent follow-ups of 7,15 and 30 days for total 30 days. 


\section{Observations and Results}

Table 2: Showing effect of therapy on systolic and diastolic blood pressure (objective parameter): (paired ' $t$ ' test)

\begin{tabular}{|c|c|c|c|c|c|c|c|c|}
\hline \multirow[t]{2}{*}{ S.No. } & \multirow[t]{2}{*}{ Variable } & \multirow[t]{2}{*}{ Group } & \multicolumn{2}{|l|}{ Mean } & \multirow[t]{2}{*}{ Mean diff. } & \multirow[t]{2}{*}{$\%$ Relief } & \multirow[t]{2}{*}{$\mathbf{P}$} & \multirow[t]{2}{*}{$\mathbf{S}$} \\
\hline & & & BT & AT & & & & \\
\hline \multirow[t]{2}{*}{1} & \multirow{2}{*}{$\begin{array}{l}\text { Systolic } \\
\text { BP }\end{array}$} & $\mathbf{A}$ & 146.37 & 124.81 & 21.56 & $14.72 \%$ & $<0.0001$ & ES \\
\hline & & B & 146.46 & 122.50 & 23.96 & $16.35 \%$ & $<0.0001$ & ES \\
\hline \multirow[t]{2}{*}{2} & \multirow{2}{*}{$\begin{array}{l}\text { Dystolic } \\
\text { BP }\end{array}$} & $\mathbf{A}$ & 91.520 & 76.00 & 15.52 & $16.95 \%$ & $<0.0001$ & ES \\
\hline & & B & 91.357 & 74.286 & 17.071 & $18.68 \%$ & $<0.0001$ & ES \\
\hline
\end{tabular}

Table 3: Effect of therapy on systolic blood pressure in both groups:

\begin{tabular}{|l|l|l|l|l|l|l|l|l|l|}
\hline S.No. & Systolic BP & $\begin{array}{l}\text { Mean } \\
\text { difference }\end{array}$ & \% Relief & SD & SE & T & P & $\Delta \mathbf{T}$ & S \\
\hline $\mathbf{1}$ & Group A & 21.556 & 14.72 & 6.727 & 1.295 & 16.649 & 0.4534 & .1248 & NS \\
\hline $\mathbf{2}$ & Group B & 23.96 & 16.35 & 7.574 & 1.431 & 16.742 & & & \\
\hline
\end{tabular}

In Group A the mean score before treatment was 146.37 which lowered down to 124.81 after treatment, which was statistically extremely significant $(\mathrm{P}<0.0001)$.
In Group B the mean score before treatment was 146.46 which lowered down to 122.50 after treatment, which was statistically extremely significant $(\mathrm{P}<0.0001)$.

Table 4: Effect of therapy on diastolic blood pressure

\begin{tabular}{|l|l|l|l|l|l|l|l|l|l|}
\hline S.No. & Dystolic BP & $\begin{array}{l}\text { Mean } \\
\text { difference }\end{array}$ & \% Relief & SD & SE & T & P & $\Delta$ T & S \\
\hline $\mathbf{1}$ & Group A & 15.704 & 17.13 & 5.532 & 1.065 & 14.751 & 0.4907 & .0248 & NS \\
\hline $\mathbf{2}$ & Group B & 17.071 & 18.68 & 4.807 & .9084 & 16.649 & & & \\
\hline
\end{tabular}

In Group A the mean score before treatment was 91.520 which lowered down to 76.00 after treatment, which was statistically extremely significant $(\mathrm{P}<0.0001)$.

In Group B the mean Score before treatment was 91.357 which lowered down to 74.286 after treatment, which was statistically extremely significant $(\mathrm{P}<0.0001)$.

On comparing the effect in case of systolic blood pressure among two groups, Unpaired t-test showed t value was .1248 for which $\mathrm{p}$ value was 0.4534 which was not quite significant.

On comparing the effect in case of diastolic blood pressure among two groups, Unpaired t-test showed t value was .0248 for which $p$ value was 0.4907 which was not significant.

\section{DISCUSSION}

a. Discussion is the basic step in establishment of a proposition \& help in reaching to definite conclusion.

b. On clinical effect of treatment:

\section{Group A- (Herbal Formulation)}

25 patients of Uccharaktachapa were treated in this group. The initial mean systolic blood pressure value of the 25 patients of this group before treatment was $146.37 \mathrm{~mm}$ of $\mathrm{Hg}$, that declined to $124.81 \mathrm{~mm}$ of $\mathrm{Hg}$ after treatment with "t" value 16.649 showing extremely significant result at $\mathrm{p}<0.0001$. Before treatment the mean D.B.P. of the 25 patients of this group was $91.520 \mathrm{~mm}$ of $\mathrm{Hg}$ and that after treatment was $76.00 \mathrm{~mm}$ of $\mathrm{Hg}$. The " $\mathrm{t}$ " value was found to be 14.751 which was statistically extremely significant at the level of $\mathrm{p}<0.0001$. 


\section{Group B- (Herbal Formulation + Gokshura Kwatha)}

27 patients of Uccharaktachapa were treated in this group. The initial mean systolic blood pressure value before treatment was $146.46 \mathrm{~mm}$ of $\mathrm{Hg}$ and which was brought down to $122.50 \mathrm{~mm}$ of $\mathrm{Hg}$ after treatment. The " $t$ " value was found 16.742 which was

extremely significant at the level of $(p<0.0001)$. Before treatment the mean diastolic blood pressure of this group was $91.357 \mathrm{~mm}$ of $\mathrm{Hg}$ which reduced to 74.286 $\mathrm{mm}$ of $\mathrm{Hg}$ after treatment. The "t" value was found to be 16.649 which was statistically extremely significant at the level of $(p<0.0001)$.

On comparing the effect in case of Systolic Blood pressure among two groups, Unpaired t-test showed t value (.1248) for which $p$ value was 0.4534 which was not significant. However herbal formulation with Gokshura kwatha showed better results than herbal formulation alone on comparison.

On comparing the effect in case of Diastolic Blood pressure among two groups, Unpaired t-test showed t value .0248 for which $p$ value was 0.4907 which was not significant. However, on comparison herbal formulation with Gokshura kwatha showed better results than herbal formulation alone.

\section{Discussion on Samprapti ${ }^{4}$}

According to classical literature of Ayurveda, Vata is prominent Dosha in this disease, circulating Rakta (Rasa-Rakta complex) is main Dushya and Rasavaha, raktavahasrotas together with Manovahasrotas are involved. It's Samprapti can be understood by the way that Vata is prominent Dosha in this disease and circulating Rakta (Rasa-Rakta complex) is main Dushya. Pitta Lakshans are also seen because of association of Rakta and pitta (Ashraya - Ashriya bhava). Ageing is one of the main factors for essential hypertension, Vata is stated as dominant in old age and signs of premature ageing are mentioned under pitta Prakriti.Agnidushti is principle source of every disease which results in Agnimandya results in Ama formation. Agnimandya gives Rasa Raktadushti as a result more and more Vikrutakapha is produced as kapha is mala of rasa dhatu. Excessive production of Vikrutakapha increases viscosity gives rise to atherosclerosis or Dhamni uplepa which is factor for hypertension and comes under kaphajananatmajavikara. Atherosclerosis and aggravated Vata gives repeated spasm resulting in increased peripheral resistance to circulating fluid. Hence hypertension can be assigned as Tridhoshajvyadhi with predominance of Vata and Pitta. $^{5}$

\section{A. Discussion on Mode Probable of Action of Combination}

Prominent Rasa of Sarpagandha ${ }^{6}$, Jatamansi ${ }^{7}$ and Ashwagandha ${ }^{8}$ is Tikta which will act on Rakta, Rasa Dhatu and their Srotas. It reduces the ama and thereby viscosity of rasa decreases which results in proper Rasa Rakta Vikshepana process. Their Ushna Veerya property causes Amapachan and Vatashamak karma. Both (Sarpagandha and Jatamansi) have effect of Nidrajanan and Raktabharshamak.

Whereas Sankhpushpi ${ }^{9}$ possesss Tikta rasa which has Aampachana and Shroto shodhana property which decreases blood viscosity and check atherosclerotic changes. Prominent Snighda Guna in Sankhpushpi has Vata Shamak property and normal Rakt rasa Samvahana. Prominent Madhura Vipaka and Sheet Veerya possess Pitta Shamaka property and check Raktadushti due to Aashrayaaashriya bhava. Sankhpushpi has Rasayana, Medhya, Sangyasthpana, Bastishodhaka and Mridurechaka property that helps in vasodilation and lowers the BP.

Arjuna $^{10}$ Twak has kashaya rasa, Rukshaguna, Sheetaveerya and Katuvipaka. Due to kashaya, Ruksha and Laghuguna, Kaphanashan karma is done.

Rasayana, Shleshma upshoshaka and Lekhana property of drugs are helpful to check the atherosclerotic changes. Hence Samprapti Vighatana by a combination of Rasayana, Medhya, Hridya. Raktashodhaka and Shleshmaupshoshaka property may be helpful in finding management of the HTN without any hazard to body that rises in long duration of modern therapy.

- On effect of Gokshura ${ }^{11}$ on EHT:

Gokshaura is having Madhura Rasa and Madhura Vipaka in addition with Rasayna and Balyaprabhav seem to alleviate all signs \& symptoms. Its Mutra Virechaiya Prabhav and Basti Shodhak karma causes elimination of kleda from the body, by there it might 
have helped to reduce the raised blood pressure. It's Madhura Rasa and Vipaka, Snigdha, Guru Guna may reduce hyperactivity of Vata and thus probably reduced Sankocha and kathinya of Srotas, along with its diuretic properties the reduction in inflammation might have resulted.

\section{CONCLUSION}

- Hypertension is a multifactorial cardiovascular disorder occurring particularly at middle and senile age.

- Herbal formulation contains combination of 5 drugs that possess Aampachana, Vaatshamak Rasayana, Medhya, Hridya. Raktashodhaka, Shleshma upshoshaka and Lekhana property which are helpful to check the atherosclerotic changes by decreasing viscosity of blood and also works on Rasarakta Samvahan by their ayurvedic properties. As Essential hypertension can be considered as a Tridoshaj Vyadhi with predominance of Vata and pitta therefore this combination mainly works on regulating movement of Vata by its Anulomana action.,by checking Rasarakta Dushti and also by removing Margavrodha that helps to reduce blood pressure.

- Sarpagandha and Jatamansi possess Nidrajanan and Raktabharshamak. property that helps in vasodilation and lowers the BP.

- Gokshura is having Rasayna, Balya, Mutra Virechaiya Prabhav and Basti Shodhak karma causes elimination of kleda from the body, by which it might have helped to reduce the raised blood pressure.

At the end of the study it can be concluded that overall (Herbal formulation along with Gokshurakwatha) was found to be more effective than Herbal formulation alone in the management of EHT.

\section{REFERENCES}

1. $2018 \mathrm{ESC} / \mathrm{ESH}$ Guidelines for the management of arterial hypertension; European Heart Journal. August 2018

2. World Health Organization.

3. Ibidem (2)
4. Agnivesh; Charak Samhita; With Charak Chandrika hindi commentary, by Dr. Brahmanand Tripathi; Chaukhambha surbharati prakashan, Varansi,2010.

5. Vagbhatta; Ashtanga Hridaya; Sarvanga Sundari commentary of Arundatta and Ayurveda Rasayana commentary of Hemadri, edited by Bhisajacharya Harisastri Paradkar Vaidyam, Chaukhambha Sanskrit series office, Varansi; 1982.

6. The Ayurvedic pharmacopoeia of India, Part-1, Vol.-5, first edition, 2001, Ministry of Health and Family Welfare Government of India, pg-166. Sarpagandha

7. The Ayurvedic pharmacopoeia of India, Part-1, Vol.-1, first edition, 2001, Ministry of Health and Family Welfare Government of India, pg-51. Jatamansi

8. The Ayurvedic pharmacopoeia of India, Part-1, Vol.-1, first edition, 2001, Ministry of Health and Family Welfare Government of India, pg-15

9. The Ayurvedic pharmacopoeia of India, Part-1, Vol.-2, first edition, 2001, Ministry of Health and Family Welfare Government of India, pg-147. sankhpushpi

10. The Ayurvedic pharmacopoeia of India, Part-1, Vol.-2, first edition, 1999, Ministry of Health and Family Welfare Government of India, pg-17-18. arjun

11. The Ayurvedic pharmacopoeia of India, Part-1, Vol.-1, first edition, 2001, Ministry of Health and Family Welfare Government of India, pg-38. Gokshura

\section{ABBREVIATIONS}

HTN : Hypertension

SBP : Systolic blood pressure

DSP : Diastolic blood pressure

AT : After treatment

BT : Before treatment

SD : Standard deviation

MD : Mean difference

SE : Standard error

CI : Confidence interval

Source of Support: Nil

Conflict of Interest: None Declared

How to cite this URL: Pooja Gautam et al: Management Of Essential Hypertension Using Herbal Formulation With And Without Gokshura Kwatha - A Comparative Study. International Ayurvedic Medical Journal \{online\} 2021 \{cited April, 2021\} Available from: http://www.iamj.in/posts/images/upload/702 707.pdf 